\title{
FIZIČKA AKTIVNOST OSOBA STARIJE ŽIVOTNE DOBI
}

\author{
Ljerka Ostojićl, Marjeta Mišigoj-Duraković \\ ${ }^{1}$ Odjeljenje medicinskih nauka, Akademija nauka i umjetnosti Bosne i Hercegovine, \\ ${ }^{2}$ Sveučilište u Zagrebu \\ Autorica za korespondenciju: \\ Ljerka Ostojić \\ ljerka.ostojic@mef.sum.ba
}

primljen: 2019, prihvaćen: 2019, objavljen: 2020.

\section{Apstrakt}

U ovom radu cilj nam je bio naglasiti pozitivan učinak tjelesne aktivnosti na kvalitetu života kod osoba starije životne dobi, ukazati na to koliko je važno njihovo znanje o utjecaju tjelesne aktivnosti na zdravlje te koje su fizičke aktivnosti optimalne u toj životnoj dobi. Dosadašnjim iskustvima, a osobito stručnim i znanstvenim istraživanjima, utvrđeno je da tjelesna aktivnost u starijoj životnoj dobi ima više prednosti. Temeljna je zadaća proširiti znanje o potrebnim tjelesnim aktivnostima i njihovom utjecaju na zdravlje, potom povećati motiviranost te populacije za tjelesnom aktivnošću i, na kraju, dati smjernice i napraviti algoritam tjelesnih aktivnosti s obzirom na dob te opću tjelesnu i mentalnu sposobnost svake osobe starije životne dobi. Zaključak je da se redovitom tjelesnom aktivnošću mnoge promjene lokomotornog i živčanog sustava, za koje se smatra da su "normalne" tzv. degenerativne promjene, a koje negativno utječu na kvalitetu života, mogu prevenirati. I najmanja tjelesna aktivnost čini osobu pokretljivijom, zadovoljnijom te omogućuje kvalitetan život i u takozvanoj trećoj životnoj dobi.

Ključne riječi: starije osobe, fizička aktivnost, kvaliteta života. 
Ljudski vijek znatno je produžen napretkom medicine i poboljšanjem uvjeta života. Na jednoj nadgrobnoj ploči piše da je osoba preminula u dubokoj starosti, u svojoj pedeset šestoj godini života. Na početku 20. stoljeća prosječno se živjelo 50 godina, a prema podacima Svjetske zdravstvene organizacije sada je prosjek duljine života preko 70 godina, s tim da žene žive dulje od muškaraca (1).

Stariju životnu dob definiramo kronološkom dobi od 65 i više godina, a čini blizu 20\% stanovništva i to je dio populacije čiji se broj najbrže povećava.

Koeficijent starosti je temeljni pokazatelj razine starenja stanovništva i odnosi se na postotak osoba starih $\geq 60$ godina u ukupnom stanovništvu. Iznad $12 \%$ označava da stanovništvo ulazi u proces starenja.

Indeks starenja označava postotak osoba starih $\geq 60$ godina u odnosu na broj osoba starih 0-19 godina. Indeks iznad 40\% ukazuje na proces starenja stanovništva. Smatra se da danas u svijetu ima 400 milijuna osoba iznad 65 godina života, a predviđa se da će ih 2025. godine biti 800 milijuna.

Proportion of selected age groups of world population in $\mathbf{2 0 1 8}$, by region $50 \%$

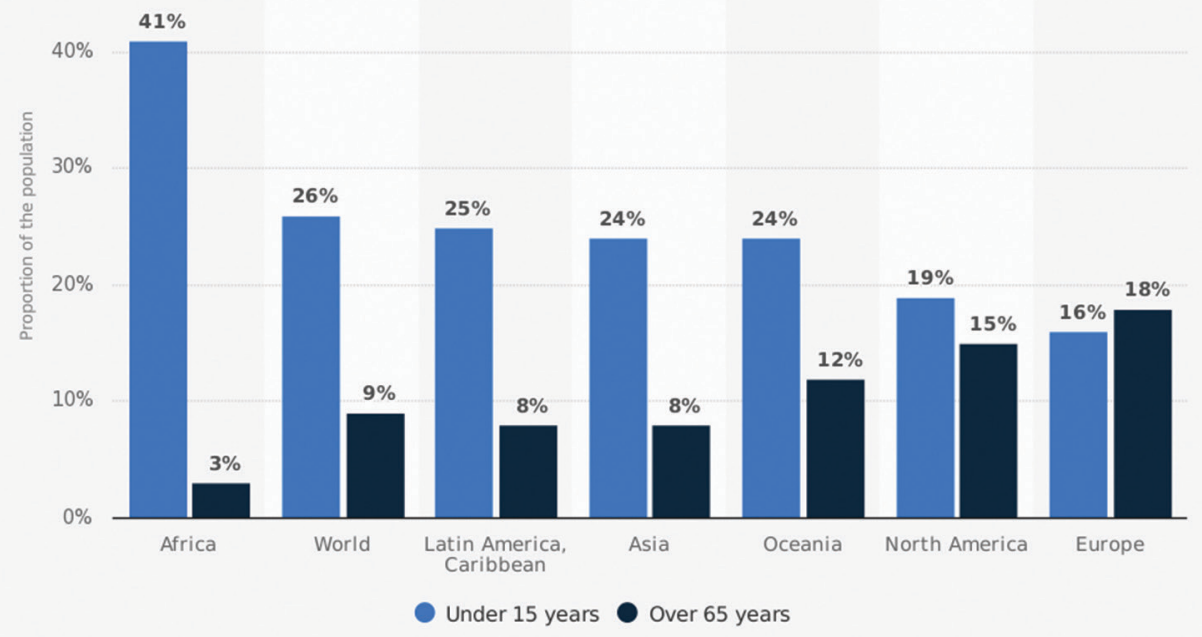

Source

Population Reference Bureau

(2) Statista 2018

Additional Information:

Worldwide

\section{statista}

Slika 1. Udio određenih dobnih skupina u svjetskoj populaciji po regijama (1)

Takvi trendovi otvaraju brojna ekonomska i socijalna pitanja. Poseban su izazov za grane medicine: gerontologiju, gerijatriju i gerontokineziologiju (2). Temeljna pitanja koja se nameću su: 
- Kako održati sposobnosti u starosti?

- Kako poživjeti dugo i kvalitetno?

- Kako smanjiti zdravstvene troškove?

Starenje se definira kao dio ljudskog života i ljudske prirode u kojem osoba s obzirom na prijašnje stanje gubi funkcije organizma te svojstva i sposobnosti (3).

Kineski zapisi spominju da je dugovječnost rezultat ravnoteže življenja: harmonija pozitivno utječe na zdravlje i dugovječnost, a do starenja dolazi gubitkom harmonije življenja. Egipćani su starost smatrali bolešću koja se može spriječiti pravilnom prehranom te uravnoteženom tjelesnom i mentalnom aktivnošću. Platon zagovara umjerenu tjelovježbu u sprečavanju starenja. Za Aristotela je starenje rezultat gubitka vode i topline tijela. Moderno doba proučavanja procesa starenja započinje u dvadesetom stoljeću, kada se u medicinu uvode pojmovi gerontologija (proučava trajanje ljudskog života) i gerijatrija (znanost o liječenju staračkih bolesti). Gerontologija ima za cilj proučavanje metoda očuvanja tjelesnog i mentalnog zdravlja te osiguranje što duže neovisnosti o tuđoj pomoći u svakodnevnim aktivnostima.

Starenje je složen proces koji uvjetuju razni faktori. Reguliraju ga višestruki mehanizmi koji se očituju na molekularnoj, staničnoj, tkivnoj, organskoj i sistemskoj razini. Brojne teorije pokušavaju objasniti proces smanjene biološke adaptabilnosti i vijabilnosti (životne snage) na genskoj razini utjecajima okoline i njihova interakcijskog djelovanja. Tri su grupe teorija: genetske (teorija pogreške, somatske mutacije i programiranog starenja), fiziološke (teorija slobodnih radikala, unakrižne povezanosti i teorija nakupljanja otpadnih tvari) i teorija promjena funkcija organa (imunološke i neuroendokrinološke teorije).

Nijednom navedenom teorijom ne može se posve objasniti fenomen starenja organizma, ali se međusobno nadopunjuju. Bez odgovora i dalje ostaje pitanje zašto starimo.

\section{Karakteristike starenja}

Primarno starenje podrazumijeva postupne i progresivne involutivne promjene organizma tijekom godina starenja obuhvaćajući promjene na molekularnoj i staničnoj razini, a zahvaćaju sve organe i organske sustave. Rezultira smanjenjem funkcionalne sposobnosti, smanjenjem sposobnosti adaptacije na stres, smanjenjem osjetnih funkcija, povećanjem kroničnih upala, smanjenom otpornošću na infekcije i povećanjem rizika na razvoj kroničnih bolesti, te u konačnici, smrti. 
Sekundarno starenje je posljedica bolesti i nezdravih navika življenja kao što su: pušenje, preobilna prehrana i nedovoljna tjelesna aktivnost.

$\mathrm{S}$ današnjim znanjima i razinom medicine nismo u mogućnosti usporiti ili odgoditi proces primarnog starenja. Međutim, prevencija sekundarnog starenja i kvalitetno produljenje očekivanoga životnog vijeka usvajanjem zdravog i aktivnog stila življenja vodi očuvanju zdravlja i funkcionalne sposobnosti.

Kronološka (kalendarska) dob je ona iznad 65 godina i dijeli se u tri skupine:

- "mlađe" starije, u dobi od 65 do 74 godine

- "starije" starije, u dobi od 75 do 84 godine

- "vrlo stare", u dobi iznad 84 godine

Fiziološka dob je definirana individualnom sposobnošću organizma da se adaptira na uvjete okoline, najčešće izražene izdržljivošću, jakošću, fleksibilnošću, koordinacijom i radnim kapacitetom. Vrhunac funkcionalne sposobnosti je u dobi oko 30 godina. U četvrtoj deceniji života funkcionalna sposobnost se postupno smanjuje različitom brzinom. Populacija starih prema fiziološkoj dobi dijeli se u tri skupine:

- "mlađi” stariji - kronološke dobi od 55 do 75 godina

- "stariji” stariji - kronološki stariji od 75 godina

- "sportski” stariji - neovisno o kronološkoj dobi

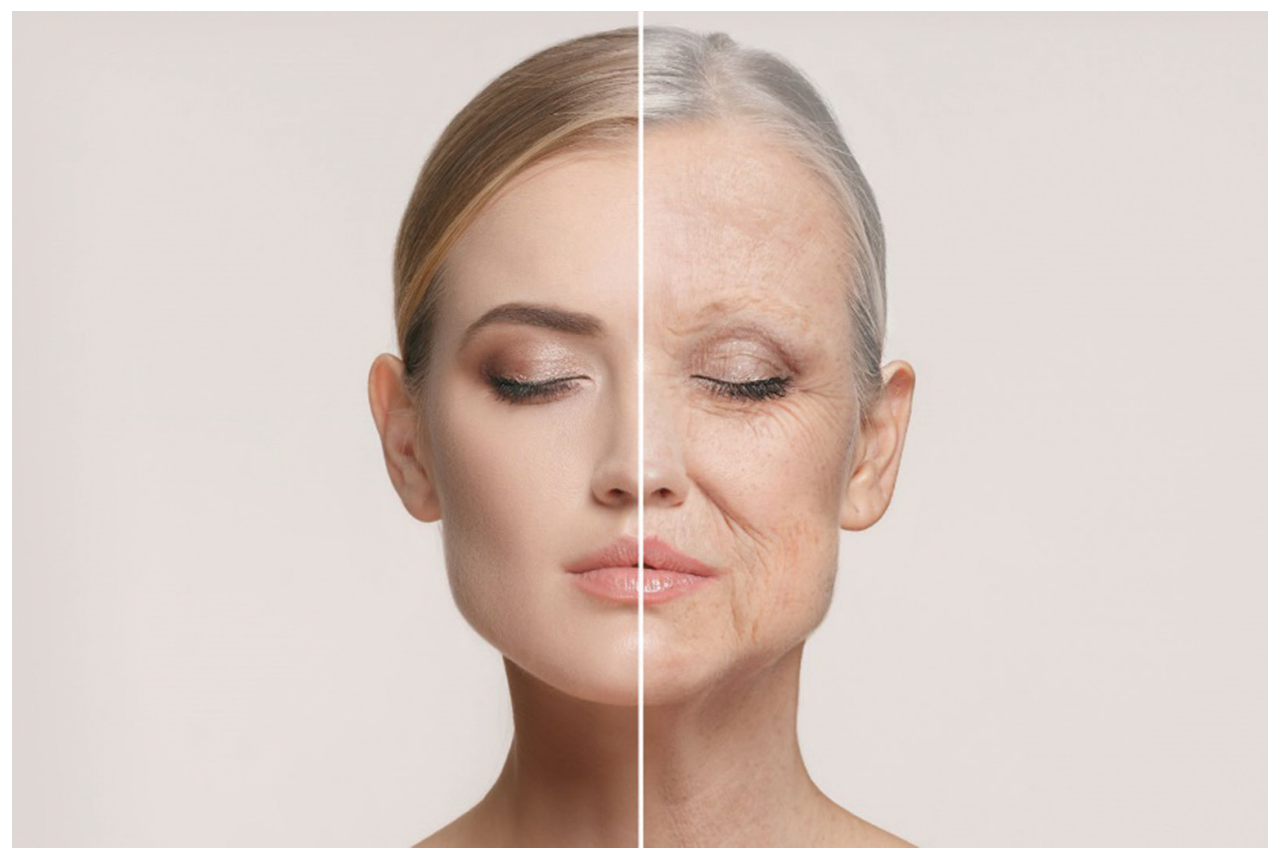

Slika 2. Starenje, ilustracija (4) 


\section{Fizička aktivnost i starenje}

Da bismo pravilno procijenili koje fizičke aktivnosti i kojega intenziteta preporučiti osobama starije životne dobi, moramo uzeti u obzir i promjene, u prvom redu, koštano-mišićnoga sustava. Poznato je da smanjenja funkcija pojedinih organa i sustava tijekom starenja nalikuju onima nastalima kao posljedica neaktivnosti. Fiziološka starost očituje se u smanjenju sposobnosti obavljanja tjelesne aktivnosti. Također se gubi masa mišića koji imaju i ultrastrukturne promjene, smanjenje gustoće tijela i povećanje tjelesne masti. Radni kapacitet, odnosno sposobnost za rad definirana je kroz aerobnu izdržljivost čovjeka. Parametar procjene radnog kapaciteta je maksimalni primitak kisika, to jest sposobnost organizma da primi kisik, da ga prenosi i iskoristi za oksidacijske energijske procese. Tjelovježba utječe na promjenu tog parametra, ali se on vremenom stalno smanjuje. Smanjuje se broj mišićnih vlakana, što rezultira smanjenjem mase i jakosti mišića. Tijekom starenja dolazi i do smanjenja gustoće kosti, što je izraženije kod žena nego kod muškaraca. Smanjenje gustoće kosti uzrokuje osteopeniju, a izrazitije smanjenje dovodi do osteoporoze. Kosti su sklonije prijelomima, najčešće kralježaka, vrata bedrene kosti i podlaktice.

Prije uključivanja u tjelesno vježbanje potrebno je obaviti medicinski pregled i savjetovanje s liječnikom. Tjelesna aktivnost starijih osoba treba biti umjerenog intenziteta, dominantno aerobna, s pridruženim vježbama mišićne izdržljivosti, fleksibilnosti i ravnoteže. Nagla povećanja intenziteta opterećenja valja izbjegavati te slijediti preporuke postupnosti u vježbanju.

Imajući u vidu sve fiziološke promjene nastale starenjem, tjelovježba u starijoj dobi ima dva glavna cilja:

- Održanje ili poboljšanje funkcionalne sposobnosti

- Sekundarnu prevenciju, liječenje ili rehabilitaciju kroničnih bolesti

Redovito vježbanje i održavanje aktivnog načina življenja pridonose prosječno očekivanom trajanju života, odnosno aktivnoga životnog vijeka, opće kondicije i poboljšanja kardiorespiratorne sposobnosti, održanju i poboljšanju mišićne i koštane mase, mišićne jakosti, fleksibilnosti i ravnoteže (5). Također, evidentan je subjektivni osjećaj poboljšanja zdravstvenog stanja (6). 
Tablica 1. Subjektivni doživljaj poboljšanja zdravstvenog stanja nakon uvođenja redovitog vježbanja (6).

\begin{tabular}{|c|c|c|c|c|c|}
\hline Od kada redovito vježbam & $\begin{array}{l}\text { U potpunosti } \\
\text { se ne slažem }\end{array}$ & $\begin{array}{l}\text { Uglavnom se } \\
\text { ne slažem }\end{array}$ & $\begin{array}{l}\text { Niti se } \\
\text { slažem, niti } \\
\text { se ne slažem }\end{array}$ & $\begin{array}{l}\text { Uglavnom se } \\
\text { slažem }\end{array}$ & $\begin{array}{l}\text { U potpunosti } \\
\text { se slažem }\end{array}$ \\
\hline Osjećam se općenito bolje, poletnije & 2 & 2 & 8 & 8 & 10 \\
\hline Lakše održavam tjelesnu težinu & 0 & 4 & 6 & 8 & 12 \\
\hline Smanjile su se zdravstvene tegobe & 0 & 4 & 5 & 16 & 5 \\
\hline Osjećam se manje umorno & 0 & 3 & 4 & 8 & 15 \\
\hline Osjećam se snažnije i sposobnije & 0 & 3 & 4 & 6 & 17 \\
\hline Sretniji sam nego prije & 0 & 2 & 5 & 9 & 14 \\
\hline Upoznao sam nove ljude & 0 & 4 & 5 & 8 & 13 \\
\hline Lakše i sigurnije se krećem & 0 & 2 & 5 & 6 & 17 \\
\hline Popravilo mi se samopouzdanje & 0 & 3 & 4 & 5 & 18 \\
\hline Nastojim se zdravije hraniti & 0 & 2 & 3 & 3 & 22 \\
\hline Zadovoljniji sam svojim izgledom & 0 & 1 & 4 & 8 & 17 \\
\hline Stekao sam nove prijatelje & 1 & 1 & 3 & 7 & 18 \\
\hline Bolje spavam & 4 & 3 & 2 & 6 & 15 \\
\hline $\begin{array}{l}\text { Smanjio se osjećaj malaksalosti i } \\
\text { iscrpljenosti }\end{array}$ & 4 & 3 & 2 & 6 & 15 \\
\hline Osjećam se manje nervozno & 5 & 4 & 5 & 7 & 9 \\
\hline Osjećam se manje umorno & 5 & 4 & 2 & 9 & 10 \\
\hline
\end{tabular}

\section{Kada, kako i koliko vježbati}

Smatra se da je čovjek sposoban za tjelesnu aktivnost sve dok živi te da godine nisu ograničenje ako se tjelesne aktivnosti prilagode aktualnome funkcionalnom i zdravstvenom statusu. Nužno je pravilno odrediti oblik i volumen opterećenja. Svaki trening treba biti doziran tako da nakon njega uvijek postoji i ostaje želja za daljnjim treningom. Najčešće se tu radi o sportsko-rekreacijskoj aktivnosti. U rekreaciji se koriste isti oblici kretanja kao u sportu, ali s drugom namjerom. U sportu je osnovni cilj natjecanje i pobjeda, a $\mathrm{u}$ rekreaciji je cilj zabava, druženje te održanje tjelesne sposobnosti i dobroga zdravlja. Naravno da u sportu ima zabave i u rekreaciji laganoga natjecanja. U rekreaciji se izborom aktivnosti i razinom opterećenja napori mogu dozirati ovisno o dobi i zdravstvenom statusu. 


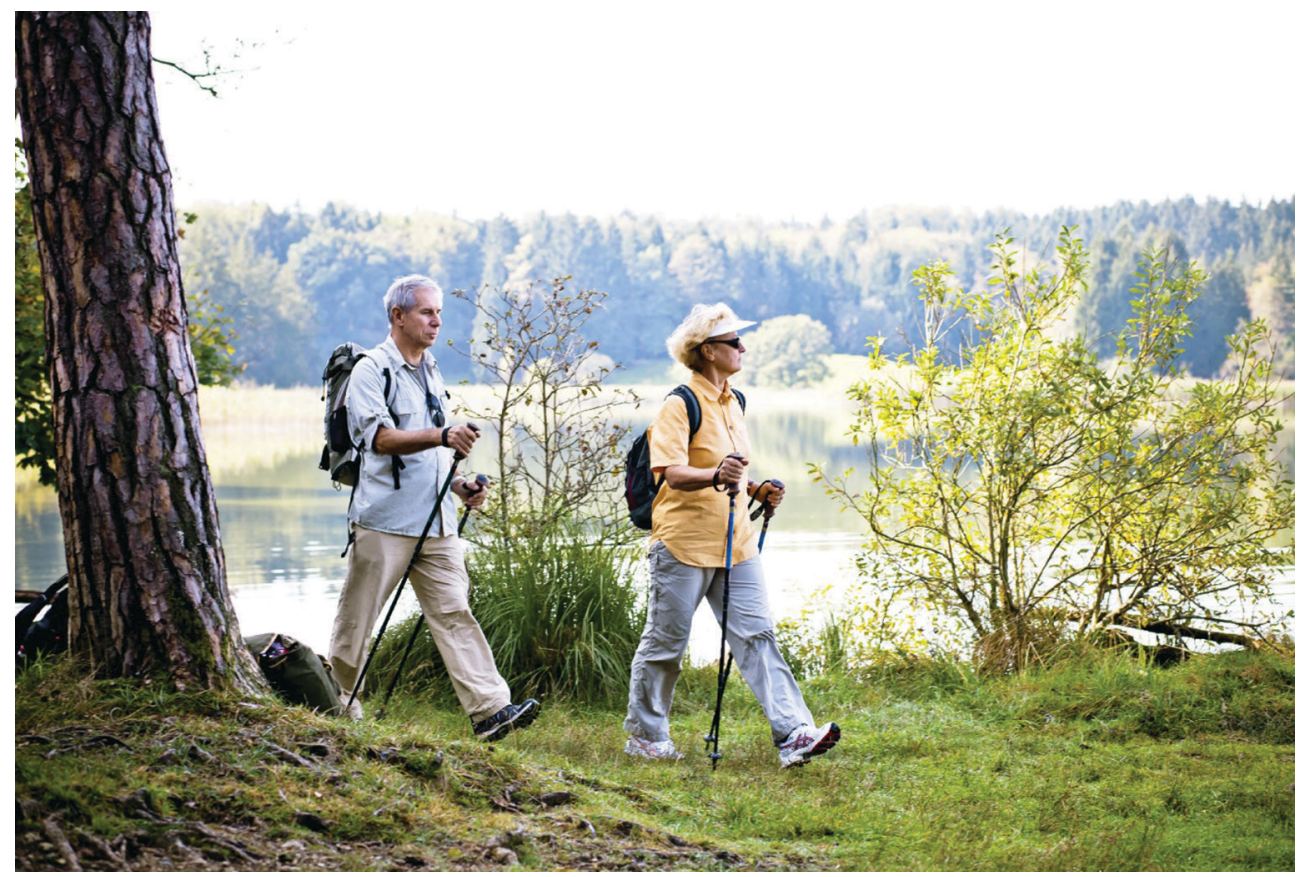

Slika 3. Hodanje po neravnom terenu (7)

Postoje određeni preduvjeti za zdravstvenu korist od tjelesne aktivnosti.

- Redovito vježbanje, ukupno najmanje 150 minuta na tjedan, najbolje svaki dan, dominantno aerobnog tipa, odgovarajućeg intenziteta. Najbolje je vježbati 30 minuta na dan jednokratno. Varijanta je i raspoređeno u nekoliko 10 do 15 minutnih razdoblja vježbanja.

- Vježbe mišićne izdržljivosti umjerenog intenziteta valja provoditi najmanje dva puta na tjedan. One su izvanredno djelotvorne i značajno stimuliraju razvoj aerobnoga kapaciteta (8).

- Aerobno vježbanje valja upotpuniti vježbama mišićne jakosti umjerenog intenziteta, koordinacije i fleksibilnosti.

- Starije osobe sa znatno smanjenim kapacitetom trebaju provoditi vježbe za poboljšanje ravnoteže i prevenciju pada najmanje tri puta na tjedan. 


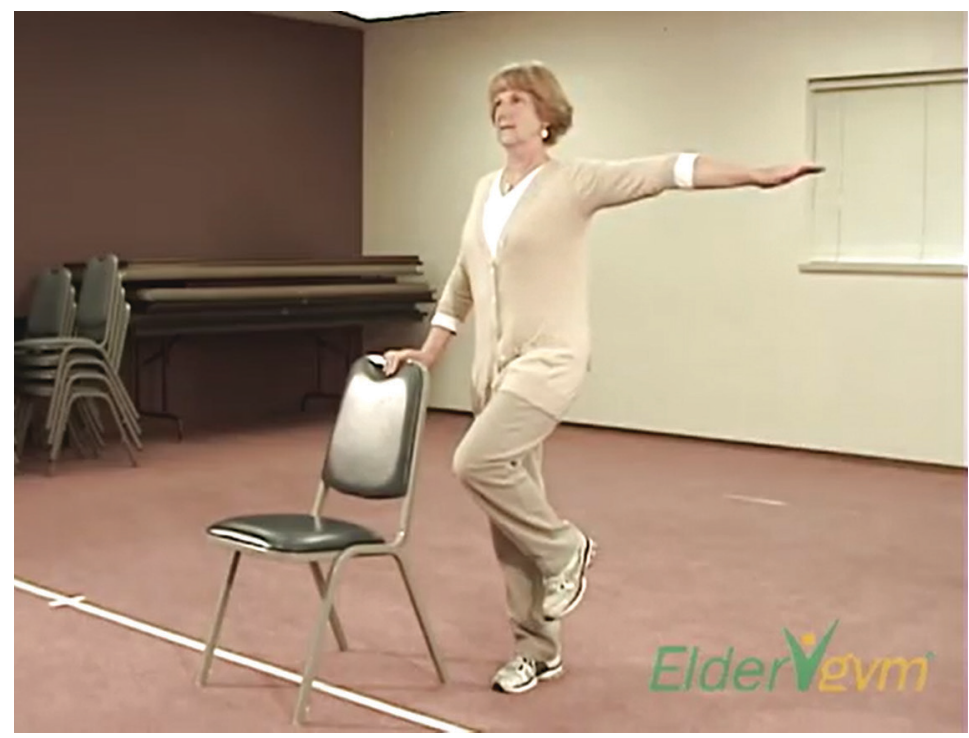

Slika 4. Vježbe za ravnotežu (9)

Pri izboru aktivnosti valja voditi računa o životnoj dobi, spolu te zdravstvenoj i funkcionalnoj kondiciji. Jasno je da su fiziološke mogućnosti ograničene u starijoj dobi. Postoje određene opasnosti nekih aktivnosti zbog veće vulnerabilnosti pojedinih tkiva u starosti. Raspon fizičkih aktivnosti je iz navedenih razloga nešto sužen. Treba davati prednost vježbama koje potiču funkcionalno poboljšanje rada srca, krvotoka i disanja, što sve skupa potiče opću izdržljivost. Za takav rezultat potrebno je ispuniti sljedeća dva kriterija: - Aktivirati najmanje 1/7 cjelokupne poprečnoprugaste muskulature.

- Vježbe moraju trajati najmanje 5 minuta u osoba slabijega funkcionalnog stanja i kronično bolesnih, u ostalih 10-15 minuta. Ponavljati ih prema mogućnostima nekoliko puta na dan, a izvode se svaki dan.

Vježbe mišićne jakosti pridonose mišićnoj snazi i ukupnoj tjelesnoj spremnosti za svakodnevne aktivnosti. Vježbe koordinacije, ravnoteže i fleksibilnosti pridonose sprečavanju padova i ozljeđivanja. Osobe stječu i osjećaju sigurnost zbog bolje koordinacije pokreta. 

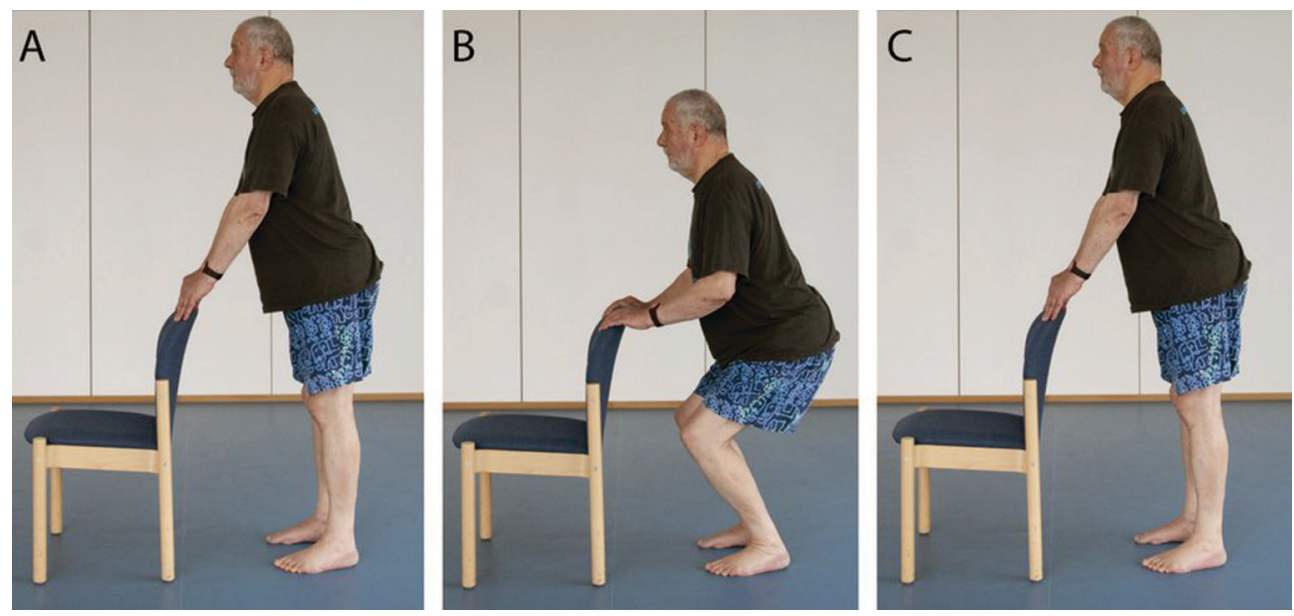

Slika 5. Vježbe mišićne snage (10)

Aerobne aktivnosti umjerenog intenziteta preporučuju se svaki dan, umjerene vježbe mišićne izdržljivosti i jakosti preporučuju se dva puta na tjedan. Redovitost i ukupni volumen vježbanja su mnogo važniji nego intenzitet vježbanja.

Specifični zdravstveni ciljevi tjelesno aktivnog načina življenja su:

- Očuvanje i povećanje stupnja zdravlja

- Prevencija razvoja kroničnih bolesti

- Doprinos liječenju i rehabilitaciji kroničnih bolesti

- Očuvanje tjelesne spremnosti

- Očuvanje kognitivnog zdravlja

- Očuvanje sposobnosti samostalnog življenja u starosti

- Produženje aktivnog životnog vijeka i osiguranje kvalitete života

Temeljne odrednice vježbanja su:

- Vrsta

- Intenzitet

- Učestalost

- Trajanje

\section{Vrste aktivnosti}

Vrijedne svih preporuka su aerobne, ritmičke aktivnosti koje zahtijevaju upotrebu velikih mišićnih skupina i koje se mogu kontinuirano provoditi, kao što 
su: pješačenje, brzo hodanje, nordijsko hodanje, lagano trčanje, ples, planinarenje, plivanje, aerobik u vodi, klizanje, trčanje na skijama, veslanje...

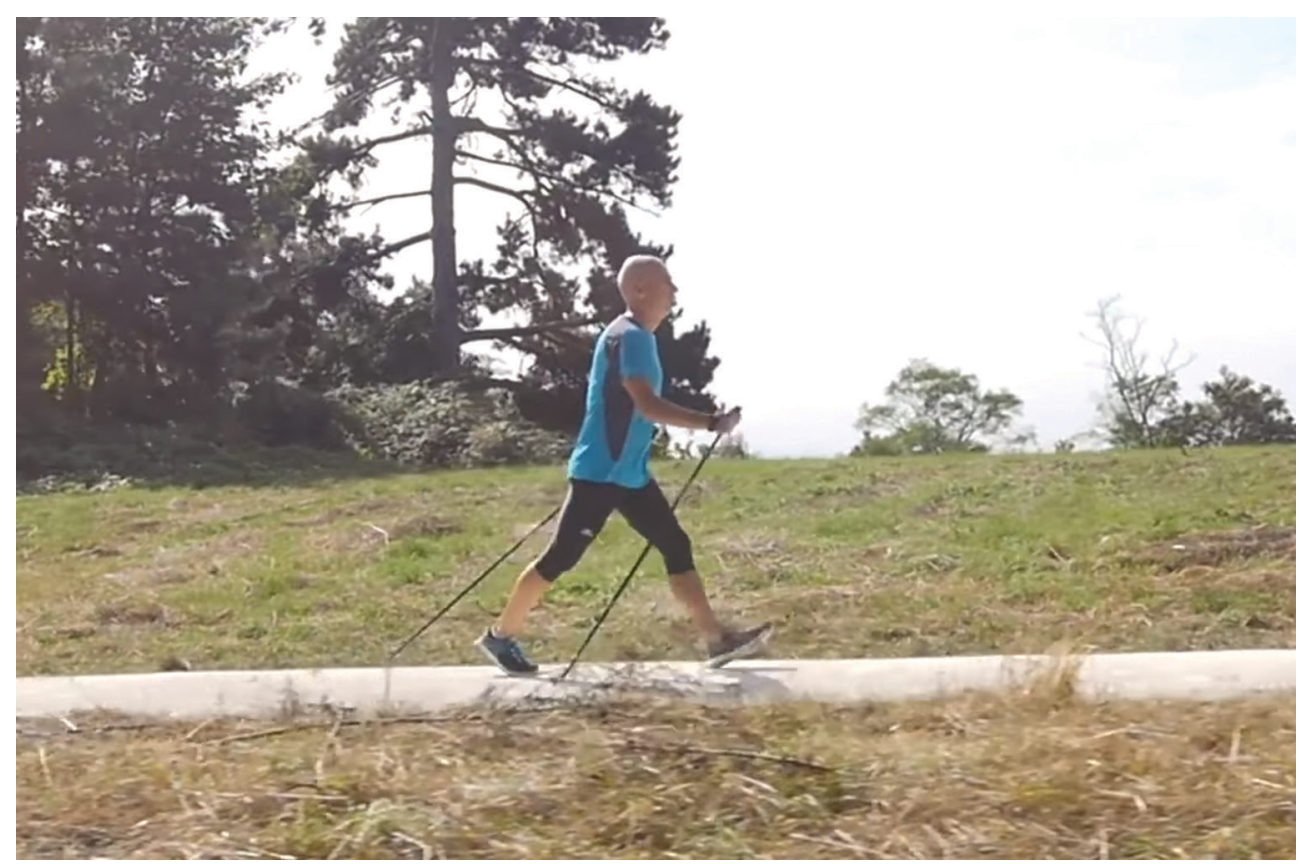

Slika 6. Nordijsko hodanje (11)

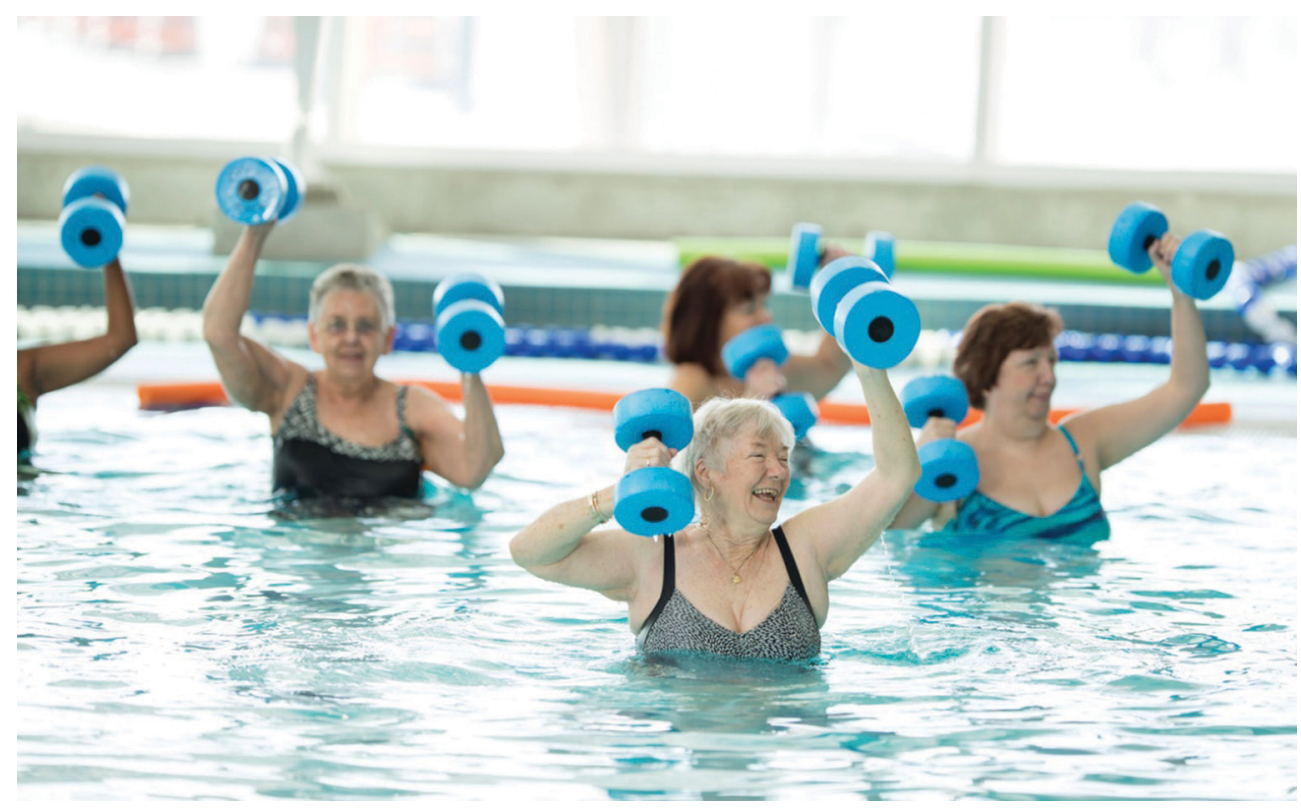

Slika 7. Aerobik u vodi (12) 


\section{Reference}

1. Population Reference Bureau. World population by age and region 2018 [Internet]. Statista. Statista, 2018 [citirano 11. 3. 2019.]. Dostupno na: https://www.statista.com/ statistics/265759/world-population-by-age-and-region/

2. Mišigoj-Duraković M. Tjelesno vježbanje i zdravlje. Zagreb, 2018;(1):111-38.

3. Lepan Ž, Leutar Z. Važnost tjelesne aktivnosti u starijoj životnoj dobi. Soc. Ekol. Zagreb. 2012;21(2):203-24.

4. Harvard Health Publishing. Why your face ages and what you can do - Harvard Health. [Internet] Harvard Health. [citirano 11. 3. 2019.]. Dostupno na: https://www.health. harvard.edu/staying-healthy/why-your-face-ages-and-what-you-can-do

5. Borer KT. Physical activity in the prevention and amelioration of osteoporosis in women interaction of mechanical, hormonal and dietary factors. Sports Med 2005;35(9):779830.

6. Ostojić L, Šimić J. Tjelesna aktivnost starijih osoba u domovima za starije i nemoćne na području Federacije Bosne i Hercegovine. Motrišta. 2019;(105):49-59.

7. Bumgardner W, Fogoros RN. Add Confidence and Stability on the Trails With Trekking Poles [Internet]. Verywell Fit. [citirano 11. 3. 2019.]. Dostupno na: https://www. verywellfit.com/how-to-use-hiking-and-trekking-poles-for-stability-4145313

8. Roksandić S, Perko G, Miuhok D, Radašević H, Ljubičić M. Živjeti zdravo aktivno produktivno starenje. Očuvanje funkcionalne sposobnosti u dubokoj starosti. Zagreb, 2005;2(17):3-31

9. Eldergym Senior Fitness. Balance Exercise - Falls in the elderly: Clock Reach [Internet]. Youtube. [citirano 11. 3. 2019.]. Dostupno na: https://www.youtube.com/ watch? v=yi01KXc7laY

10. Strength exercises: Mini Squats [Internet]. The NHS website. NHS. [citirano 11. 3. 2019.]. Dostupno na: https://www.nhs.uk/live-well/exercise/strength-exercises

11. Sikana English Learning the Basic Technique | Nordic Walking [Internet]. Youtube. [citirano 11. 3. 2019.]. Dostupno na: https://www.youtube.com/watch? $=\mathrm{vAmsHhc} 2 \mathrm{zCw}$

12. David York Agency. Home Healthcare [Internet] [citirano 11. 3. 2019.]. Dostupno na: http://davidyorkhomehealthcare.com/wp-content/uploads/2017/12/senior-arobics.jpg 


\title{
PHYSICAL ACTIVITY OF THE ELDERLY
}

\begin{abstract}
Our goal was to evidence the positive effect of physical activity on the quality of life of elderly people, highlight the importance of their level of knowledge about the impact of physical activity on health and to indicate what form of physical activity is optimal for that age. Prior experience and especially scientific research have concluded that physical activity in an elderly age has many advantages. Our main goal is to spread the knowledge about the need for physical activity and its impact on health, to raise the motivation of targeted population for physical activity, and lastly, to give guidelines and make algorithms of physical activity regarding age, general physical and mental fitness of each elderly person. In conclusion, regular physical activity may prevent many changes in the musculoskeletal and nervous systems which are considered "normal" (so called degenerative changes) that negatively affect the quality of life. Even the slightest physical activity makes a person more mobile, happier and enables a better quality of life in the so called third age.
\end{abstract}

Keywords: elderly people, physical activity, quality of life. 